\title{
(2) OPEN ACCESS \\ Countering tobacco industry tactics on the economic costs of restricting menthol tobacco
}

\author{
Kristen Ackert 이, ${ }^{1}$ Betsy Brock, ${ }^{1}$ Samantha C Friedrichsen, ${ }^{2}$ Jeanne Weigum, ${ }^{1}$ \\ Molly Moilanen, ${ }^{3}$ Raymond Boyle, ${ }^{4}$ Jodie Briggs, ${ }^{5}$ Barbara Schillo ${ }^{5}$
}

\begin{abstract}
${ }^{1}$ Association for NonsmokersMinnesota, Saint Paul,

Minnesota, USA

2Professional Data Analysts, Minneapolis, Minnesota, USA ${ }^{3}$ ClearWay Minnesota, Minneapolis, Minnesota, USA ${ }^{4}$ Tobacco-Related Disease Research Program, University of California System, Oakland, California, USA

${ }^{5}$ Truth Initiative Schroeder Institute, Washington, District of Columbia, USA
\end{abstract}

Correspondence to Mrs Kristen Ackert, Association for Nonsmokers-Minnesota, Research, Saint Paul, MN 55114, USA;

kristenlwerner@gmail.com

Received 18 March 2020 Revised 29 April 2020 Accepted 8 May 2020 Published Online First 30 June 2020
Localities around the country have begun to restrict the sale of menthol tobacco products, which are easier to start, disproportionately used by young people and are more difficult to quit. ${ }^{1}$ In 2017 , Minneapolis and Saint Paul City Councils overcame significant opposition by the tobacco industry to restrict the sale of menthol tobacco to adult-only tobacco and liquor stores. Prior to the cities' actions, the tobacco industry warned of catastrophic financial losses of between US\$36.7 and US $\$ 39.9$ million, as well as a loss of 630 jobs. $^{2}$ In order to examine the potential economic cost of a menthol ordinance and the impact on the tobacco retailer market since implementation, researchers examined national and regional sales and profit trends for top retail categories as well as online convenience industry sources and the number of tobacco retailers in each city.

\section{FAR LESS SEVERE FINANCIAL IMPACT}

Since menthol reflects about one-quarter of cigarette sales in Minnesota, we calculated a loss of US $\$ 1519 /$ month per store and projected annual profit losses of US\$6233976 for Minneapolis and US\$4737280 for Saint Paul, respectively (figure 1). These projections contrast sharply with tobacco industry estimates of financial losses of at least six times greater. Industry claims of an immediate and detrimental cost to retailers from not only loss of tobacco sales but of other items shoppers purchase when buying tobacco, like chips and soft drinks, appear to be greatly overstated. Our research found that convenience stores profit more from prepared foods and packaged beverages than tobacco. We summarised our findings into an infographic (figure 1) and shared it with decision-makers during the policy campaign. Although we could not definitively determine the impact on jobs, the number of tobacco retailers in both cities remained largely the same as it was prior to implementation, suggesting economic stability. Federal statistics support this notion, with both overall employment and retail employment in the Minneapolis-Saint Paul metro area either increasing or remaining relatively steady since 2018. ${ }^{34}$ Tobacco and alcohol retailer exemptions did create some unintended consequences in the form of 'hybrid' stores with additional tobaccoonly rooms designed to get around restrictions. Both cities have mitigated these actions by limiting the number of tobacco shops and/or enforcing tobacco retailer density requirements.

\section{SUPPORT FOR MENTHOL RESTRICTIONS}

Despite industry projections of significant financial and job loss under menthol restrictions, the Minneapolis and Saint Paul examples suggest that it is possible to successfully implement flavour regulations without an overwhelmingly negative economic impact. States and localities considering
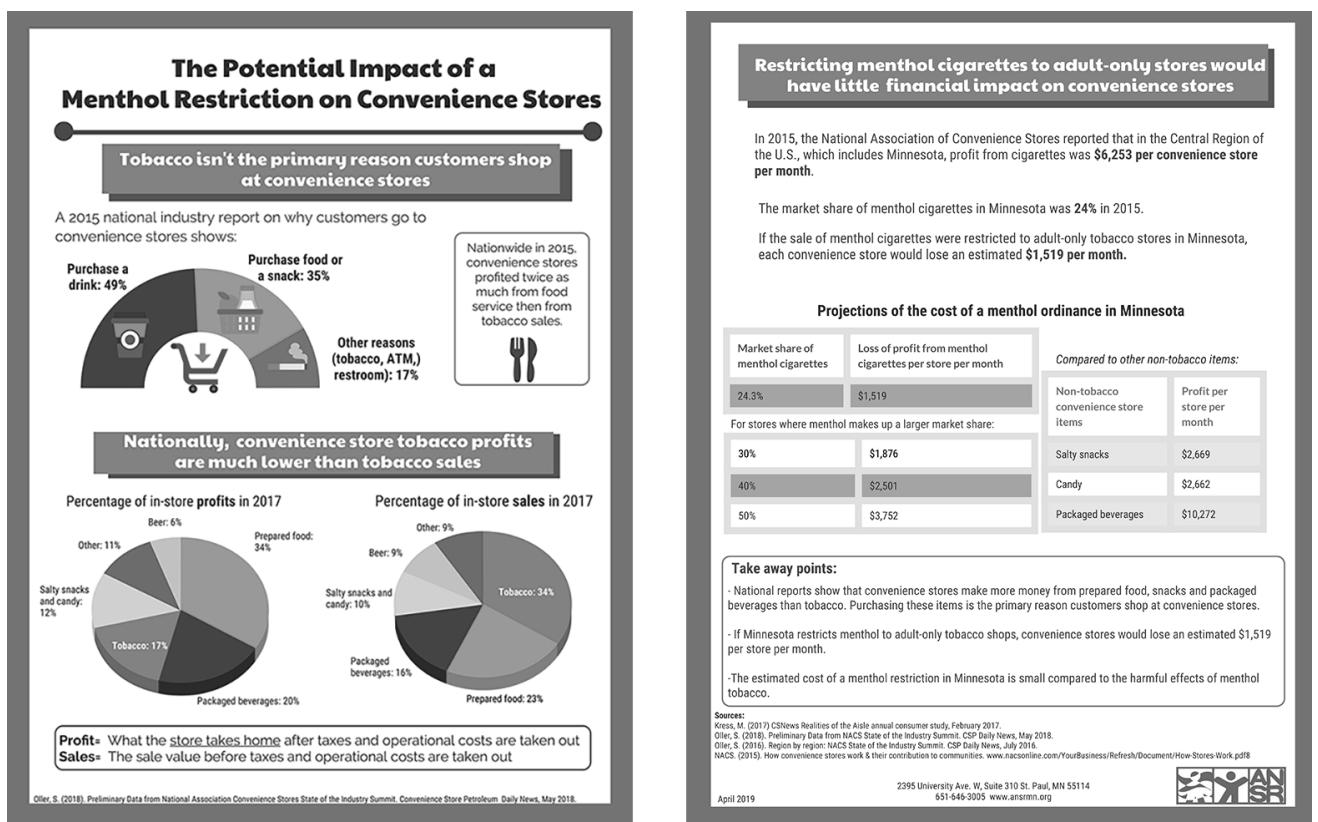

Figure 1 The potential impact of a menthol restriction on convenience stores. 
such policies may encounter strident opposition but, along with their communities, should investigate possible financial impacts themselves and be prepared to counter industry-sponsored talking points. Using convenience retail data is a quick, costeffective method to inform decision-makers and can be easily replicated by those advocating for menthol regulation. The cost of tobacco use is much higher than the economic impact of most flavour restrictions and advocates and policy-makers must not be afraid to take action to protect public health.

\section{Twitter Betsy Brock @BetsyBrock82}

Acknowledgements The authors would like to thank and recognise the following people and organisations for their work on the research that supported this paper: Professional Data Analysts, Damone Presley, LaTrisha Vetaw, members of the Minnesota Menthol Coalition.

Contributorship statement KA provided input on the study design and led the development and writing of the paper. BB provided input on the study design, data analysis and was involved in writing and review of the paper. SCF conducted data analysis, and was involved in drafting and critically reviewing the paper. JW provided input on the study design. MM assisted with study design and reviewed the paper. RB provided input on study design and critically reviewed the paper. JB provided extensive support on writing and reviewing the paper. BS provided input on study design and critically reviewed the paper. All authors have reviewed and approved the final version of the submitted paper. KA is responsible for the overall content.

Funding This work was supported by ClearWay MinnesotaSM contract \#PA-20180005.

Competing interests None declared.

Patient consent for publication Not required.
Ethics approval: Given this study does not involve human participants, IRB approval was not necessary.

Provenance and peer review Not commissioned; externally peer reviewed. Data availability statement All data relevant to the study are included in the article

Open access This is an open access article distributed in accordance with the Creative Commons Attribution Non Commercial (CC BY-NC 4.0) license, which permits others to distribute, remix, adapt, build upon this work non-commercially, and license their derivative works on different terms, provided the original work is properly cited, appropriate credit is given, any changes made indicated, and the use is non-commercial. See: http://creativecommons.org/licenses/by-nc/4.0/.

\section{ORCID iD}

Kristen Ackert http://orcid.org/0000-0002-4446-5761

\section{REFERENCES}

1 Campaign for Tobacco-Free Kids. States and localities that have restricted the sale of flavored tobacco products., 2020. Available: https://www.tobaccofreekids.org/assets/ factsheets/0398.pdf

2 Management Science Associates, Inc. Economic impact analysis: Minneapolis menthol tobacco ban, 2017. Available: http://www.ansrmn.org/wp-content/uploads/2019/ 07/Minneapolis-Menthol-Mint-and-Wintergreen-Economic-Impact-Study-SummaryOctober-2017.pdf [Accessed 3 Feb 2020].

3 U.S. Bureau of Labor Statistics. Employed and Office of Employment and Unemployment Statistics : Total Nonfarm - Total Nonfarm, Minneapolis-St. PaulBloomington, MN-WI, 2015-2019. Available: https://beta.bls.gov/dataViewer/view/ timeseries/SMS27334600000000001; jsessionid=23704EC9182F06C77D8B551A 293F208E [Accessed 29 Jul 2019].

4 U.S. Bureau of Labor Statistics. Employed and Office of Employment and Unemployment Statistics : Retail Trade - Retail Trade, Minneapolis-St. PaulBloomington, MN-WI, 2015-2019. Available: https://beta.bls.gov/dataViewer/view/ timeseries/SMU27334604200000001 [Accessed 29 Jul 2019]. 